\section{Julie McKeown}

is head of consulting at the Sorath Partnership, a business she set up two years ago with her husband. She is also an associate consultant at the University of Central England, an examiner for CIM and $a$ chartered marketer.

Keywords: business, network, groups, Shropshire, BNI

Julie McKeown

Upper Camnant

Dolfor

Newtown

Powys

Tel: +4401597840456

Fax: +4407967 970123

E-mail: julie@sorath.co.uk

\section{Papers}

\section{Business breakfast groups Worth getting out of bed for?}

\author{
Julie McKeown \\ Received: 10 May 2006
}

\begin{abstract}
Word-of-mouth marketing via creating networks, mainly through business breakfast groups, web-based communities and the like, is fast becoming a major channel to market for small businesses, especially start-ups. Many groups are now international — such as BNI (Business Network International), which started in the USA and now has groups across the globe. These types of network groups are franchise businesses in themselves with the members as their customer base. The business model is very simple: representatives from businesses gather round a table over breakfast (or sometimes in the evening) to refer work to each other. They each act as a salesperson for colleagues in the group during their daily business interactions, actively trying to get them introduced into new areas of opportunity.

Groups such as BNI work on a trust basis; as confidence in your colleague around the table grows, you are happier to refer him or her to someone you know. It is claimed to be a cost-effective method of marketing - but does it work? The author has conducted a small study based on businesses in the Shropshire and Staffordshire areas that belong to such network groups, and the initial results indicate that for some professions or trades it is a very useful form of marketing.
\end{abstract}

\section{Introduction}

For small businesses, especially those just starting up, marketing can be a minefield. Many companies look at it tactically and as an addition to the main thrust of the business. As marketers we know that it should be that it should be integrated across the whole company. As Kotler ${ }^{1}$ stated, 'Marketing does not work when it is merely a department; it works only when all employees appreciate their impact on customer satisfaction.'

Marketing can often be seen as an expense that does not appear always to pay dividends to smaller businesses. One small business owner recently remarked, 'I stuck an ad in the Admag one month and got loads of business, and did exactly the same the next month and got nothing, so I'm not doing it again.' This is typical, showing that there is little forward planning, targeting, measuring or full understanding of what returns are expected or the nature of marketing and what it can do for a business if executed properly. A lot of this of course is due to budgets - company owners often believe that marketing is an expensive overhead. This is certainly true if it is not reaping the right rewards for a business, especially a small enterprise. 


\section{Business network groups}

Study
Marketing in smaller companies is often seen simply as a choice between advertising, direct mail or Yell.com (or similar). Even websites are often built without thought of how they can be used best as a channel to market. Within this often hit-and-miss environment another form of marketing has sprung up - business network groups. A search of the web using the keywords 'business network breakfast groups' brought up a plethora of different business networking groups around the UK. Many were aimed at women or entrepreneurs, but the majority were geography based, aiming at local businesses. A similar search using 'internet business network groups' again brought up a very long list of ways of networking over the internet that included specific groups such as LinkedIn and BizWiz, both operating globally.

Kotler believes that if you build a good network of relationships with key stakeholders, profits will follow. ${ }^{2}$ The web-based groups allow you to do this, but because of the potential numbers of contacts involved it can often be difficult to know where to start and requires some dedication and a fair amount of time really to use them to their optimum potential. But, for some, they really work. One consultant colleague has spent a lot of time in business chatrooms and with online network groups and has now started to reap the rewards, but it has taken her a while to build up the contacts that she needed.

The principle of the business breakfast, or network groups (some groups meet at other times), is to act as another sales team for your colleagues, looking for business for them in the course of doing business for yourself during the week. During the meeting, the members get a chance to educate everyone else about their business and ask for the type of referral that they are looking for that week. Often one referral for one company can lead to a whole string of them, bringing in a number of people around the table. For example, a referral for a builder can often lead to ones for an electrician, a plumber, a decorator and even a garden services contractor.

The cost of membership for a year is often no more than a single advert in a local newspaper and can reap many rewards. Having to get up at an unearthly hour (the meetings usually start before 7am) can be seen by some people as a down side, but this is overcome once the business starts to come in. Whether the groups meet for breakfast or after work (they are almost never during the business day) the principle is the same.

\section{But, does it work?}

This research aimed to find out if the claims of earning many thousands from being a member of one of the breakfast groups (BNI) were true of both it and others. According to the executive director for BNI in Shropshire and Staffordshire, in $2004 £ 170 \mathrm{~m}$ of business was generated from 500,000 referrals in BNI UK alone. The worldwide figure for the same time frame was $£ 850 \mathrm{~m}$ from 3.3 million referrals, according to Allison Timmins of BNI. This gives a UK average of $£ 340$ per referral and a global average of $£ 258$ per referral.

As this was a small study, it was decided to concentrate on the Shropshire area for three reasons. 
- Ease of reaching the participants of the study: the majority were the members of two main business groups in the Shrewsbury area. The author is a member of one and has strong links with the other.

- Over 95 per cent of businesses in Shropshire have fewer than ten people working for them (according to 2004 figures from the Shropshire Chamber of Commerce).

- Shropshire is a mainly rural area, and it was of interest to see if this type of marketing was successful in this environment.

\section{Online questionnaire}

\section{Respondents}

The primary research method was an online questionnaire sent out to members of two BNI groups (or chapters) in Shrewsbury, WiRE (Women in Rural Enterprise) and others. There were 35 responses, mainly from the BNI members: 30 respondents were a member of BNI; eight of these were also members of another networking group. Short interviews over a period of time with around half of the questionnaire respondents also took place. Secondary research included background research via the web on the different business groups and attendance at meetings where key personnel from the groups were speaking. Web-based research on the respondents, including perusal of their own sites where applicable as well as Yell.com and similar directories, provided background information.

Respondents who were a member of BNI and other groups said that they gained more revenue from BNI than other groups. In fact the majority claimed to get very little from groups other than BNI. However, the respondent who claimed to get the most annual revenue $(£ 170,000)$ from networking groups was not a current member of BNI but had been until one year ago. This business is currently a member of five different groups in the area.

The network groups ranged from one aimed at women (WiRE) through those that were a business in their own right such as BNI or INC (Independent Network Club) to those affiliated to a certain industry such as the Food Manufacturing Forum and Black Country Training Providers. County chambers of commerce and web-based network groups were also mentioned.

\section{Main research findings}

The respondents were split into trades (15 responses) and professional (20 responses). Tradespeople were mainly $\mathrm{B} 2 \mathrm{C}$ (business to consumer) and the professionals mainly B2B (business to business), although there were a few anomalies such as complementary therapists. The respondents were asked to say how much revenue they received per annum from the group and what percentage this was of their total business. The average revenue across the whole group was $£ 26,000$. This happens to be the figure that BNI's Alllison Timmins claims is the average amount a seat in BNI in the UK is worth.

The professionals averaged $£ 45,000$ per respondent and the trades averaged $£ 12,000$. The range for the professionals was $£ 0-170,000$ and for the trades was $£ 10,000-35,000$. This made membership more of a certainty for tradespeople, but with less opportunity for large revenues than the professional services sector. 


\section{'Confidence curve'}

\section{Business network groups are good for getting a business off the ground}

It must be noted that a small percentage of the respondents did not answer the question regarding the amount of revenue gained per annum, instead simply noting the percentage of total business, and therefore these were omitted from the results.

The percentage of total business revenue from network groups was dependent on the size and type of business. Consultants who were sole traders and had been a member of their group for at least a year or more had revenues that were well over 50 per cent of their total income on average, whereas much larger companies saw the percentage decrease, as would be expected.

The less time as a member the lower the revenue, as the 'confidence curve' - described as the build-up of trust by other members as the relationship grows which gives them confidence to give a referral - takes time to take hold. ${ }^{3}$ This curve tends to flatten after two or three years, judging by the results, as the respondents with the highest revenues tended to be those who had been members for between 18 months and three years.

From a perusal of statistics regarding the receipt of referrals (and therefore business) within one of the groups, those offering lower-priced and less specialist services (such as gifts and office stationery) received the highest number of referrals but lower revenues. For a business such as a consultancy, referral may not be received very often but each one can be worth many thousands of pounds of revenue as they often lead to ongoing business. This would then give the opportunity to get other members into that client. An example of this is a financial adviser getting a marketing consultant into a small manufacturing company. This led to a design agency getting a referral as well as a telemarketing company, a business consultant and finally an HR consultant. Most of the business is medium to long term, and amounted to thousands of pounds for the businesses involved.

Business network groups would appear to be a good way of getting a business off the ground. Companies that had been trading for less than two years were getting $£ 11,000$ a year on average from their groups, with one consultancy obtaining $£ 35,000$. All of these were sole traders or very small businesses. Companies that have been trading for a longer time (up to $25+$ years) but remaining fairly small (up to 35 employees) were reaping higher rewards.

\section{Other marketing}

The networking groups are not the only form of marketing for the majority of the companies involved, with just over half of the respondents being listed on Yell.com. There was an even split between professional services and the tradespeople. This split was much different when looking at websites, with 14 of the professionals having sites and only six of the trades using the internet as a shop window. Leaflet drops and advertising were regularly used forms of marketing for the trades section of the respondents, whereas the professional sector tended to prefer using newsletters, seminars and editorial as ways of generating awareness in the market as a whole and retaining their client base. 
It is not known how much money is spent on these other forms of marketing and whether they are executed within some form of longerterm strategy or simply as a short-term tactic. Measurement of these campaigns against targets is also an unknown. Anecdotal evidence makes the author believe that the latter does not take place, often because targets have not been set in the beginning.

Cold calling is also employed as an alternative to advertising and PR; it has a lower budget than advertising but can be a thankless task. Referrals (warmed-up leads) are much easier to close and can cost less to obtain. They start with a higher level of trust for the product or service offered, and the use of referrals can help to build a successful business based upon word of mouth. ${ }^{4}$

\section{Value gained}

Not every company was more than recouping its membership fee from the networking groups, however. Ten per cent of the respondents were getting very little out of them, and some of these were debating leaving. A small number of businesses within the groups had been members for over a year, gaining little or no business, and were still renewing the membership despite it costing hundreds of pounds. The reason for this is unclear, but all members stated that they attained benefits other than business referrals.

The main value gained was based around what they could give to, and receive from, the others in their group. Friendships and social life were ranked the highest with eight responses, along with information and idea sharing, support, business contacts and confidence (especially with public speaking) which all had six or seven members citing these as benefits. Comments included:

'BNI provides good network links to build business partners and has to be a must for those who want to develop their business no matter how large or small.' (Independent financial consultant.)

'We will need a number of commercial services and the concept of the business network gives us a framework to ensure that we receive a quality service.' (Web services.)

'An excellent opportunity to get to know competitors and forge partnerships with them.' (Training consultant.)

There is also a negative reason for staying within a group even if it is not financially viable - 'category hogging', or a way to 'lock out' the competition from joining (some groups have only one 'seat' per business category.)

\section{Differences in revenues}

But why are some companies getting much more out of the network groups than others in the same (or similar) business categories within the same region? There were two or three examples of large differences in revenue, and from the answers on the questionnaire it is difficult to understand why, as on paper there is often very little difference in size, 


\section{Differences}

\section{Trust, relationships and loyalty}

\section{Caveats}

age and coverage between the businesses in question. Looking at websites and business cards from these companies shows that there are differences in qualifications and experience (some websites hold a profile of the company owner) as well as brand image.

Personality no doubt comes into this as well. People buy from people, and, as has been described before, trust plays a large part in building up the 'confidence curve' with colleagues in a group. A member needs to have enthusiasm for his or her offering and be able to communicate this to colleagues round the table. Once the members really believe that someone can produce the goods then the referrals will start to flow. (This information is anecdotal, based upon informal discussions, and further research would need to be done to prove this hypothesis.)

Just as companies today practice CRM (customer relationship management) when marketing to their customers and prospects to engender loyalty, trust and partnerships (among other things), so the members of network groups should proactively embrace the tenets of $\mathrm{CRM}^{5}$ when dealing with each other. The central philosophy of the groups is based upon trust, relationships and loyalty among the members to help each other get business - very similar to that of CRM.

Members are expected to act within the ethics of their business and a professional attitude is therefore very important. As each member is a potential sales channel, customer or supplier to the others around the table, it is critical to have the appropriate attitude and image within the meetings. Members often 'test' new members within their own business or homes before referring them on to their own contacts in order to lessen the risk to themselves of referring someone who does a bad job.

\section{So, what does this mean?}

For a small business in Shropshire, especially a young company with a small marketing budget, joining a business network group has to be a positive step forward. But it does have its caveats. It would appear that the member must be able to give confidence to the others that the company really does offer a quality service before business starts to flow. For young companies in the trade environment with a lower-cost offering this is easier to achieve as there is less risk attached. This is possibly why the revenue range for the trades is lower than that for professional services, but there is an almost guaranteed income, however small, based on the results of the study.

Larger and more established companies can still gain business from networking groups, especially in the services industry. One respondent's company had been in business for 26 years, has 35 employees and was receiving $£ 80,000$ of business a year from four groups. (Interestingly, the company was based in Shrewsbury but the groups were based in towns and cities over 50 miles away rather than locally.) Another long-standing local company was a member of two local groups and received over $£ 100,000$ of business per annum. Both companies are in the B2B services sector. Other, younger companies which are competing in this industry are not generating as much revenue, as they are either working in niche 
areas, building up their reputation in mainstream business, or are simply too small to cope with large contracts.

Companies in the $\mathrm{B} 2 \mathrm{C}$ sector tended to receive lower amounts of business over the year regardless of the company's age, with larger revenues going to the firms which had been in a group for over 12 months and had a greater number of employees. Further research would need to be done to get more information, focusing on this sector and the range of products and services offered. At first glance, from the results given, it would appear that their offerings are lower cost than the professional services sector and therefore lower revenues are achieved.

There did not appear to be a big distinction between B2B and B2C in ensuring success, which was surprising given the demographics of the region. This may be because many of the B2B members were targeting small businesses, and Shropshire has a great many of those.

\section{Research limitations}

The research was limited in a number of ways. Firstly, despite having a quantitative aspect, it was still very much an interpretivist piece of work, meaning that it is unlikely to be replicable across other areas. This would have to be tested by repeating it across other rural counties in the UK. Secondly, it is an exploratory piece as the majority of responses came from two BNI chapters based in Shrewsbury. Shropshire has many other

\section{Limitations of} research groups (both BNI and others), but reaching them was difficult within the timescales given for this research. Thirdly, the design of the research (secondary research, questionnaires and some interviews) had the scope for much more information being brought out and this could be included in any further research being done on the subject. Finally, there was no control group - especially start-up businesses. Therefore it is unclear how easy it is for new businesses to penetrate their chosen markets without the help of the groups. New businesses (under one year old) were generating some revenue from the groups but were also fairly new to them, and so had not built up the levels of confidence needed to get many business referrals.

This piece of research came from a desire to understand the dynamics of networking groups within the county and why there appeared to be so many in such a small geography. The author is a member of BNI Pengwern in Shrewsbury and WiRE, as well as having links into BNI Darwin Shrewsbury. Other contacts gave the opportunity to widen the research, but responses from these turned out not to be as numerous as planned and so the result was a narrower study.

\section{Further research}

As the internet is now a major communications channel for businesses of all types, investigation to compare how web-based networks and geographic business breakfast groups actually help local companies would be of use. As soon as the internet is used (whether a website, chatroom or other) there is global reach. Is this applicable to the majority of small companies? The hypothesis is that for the majority the breakfast groups would bring more benefit — but who knows? 


\section{References}

1. Kotler, P. (1997) Marketing Management, Prentice Hall, London, p. 24.

2. Ibid., p. 13.

3. Georgevich, D. (2003) 'SuccessNet', available at www.bni.com/successnet2005/Nov_Dec_2003/ print.

4. Misner, I. R. 'The world's best known marketing secret', available at www.entrepreneur.com/ article/0,4621,322530,00.

5. Stone, M., Woodcock, N. and Machtynger, L. (2000) Customer Relationship Marketing, Kogan Page, London, pp. 3-6. 